\title{
IDENTIFIKASI PROFIL KUMUH KELURAHAN GONDORIYO, KECAMATAN NGALIYAN, KOTA SEMARANG
}

\author{
Agus Sarwo Edy Sudrajat a, Kamal Alfandy Sasono b \\ aUniversitas Semarang; JI Soekarno Hatta Semarang; agussarwo@usm.ac.id \\ bUniversitas Semarang; JI Soekarno Hatta Semarang; kamalalfandy10@gmail.com
}

Info Artikel:

- Artikel Masuk: 03/03/21

- Artikel diterima: 21/03/21

- Tersedia Online: 30/03/21

\begin{abstract}
ABSTRAK
Kota merupakan pusat aktivitas penduduk yang dilengkapi dengan berbagai sarana dan prasarana sebagai penunjuang kebutuhan hidup penduduknya. Semakin hari kota semakin berkembang seiring dengan pertumbuhan penduduk yang semakin meningkat, baik karena faktor urbanisasi maupun faktor lainnya. Pertumbuhan penduduk pada suatu kota tentunya akan berdampak pada kebutuhan akan ruang baik minimal sebagi tempat tinggal untuk hidup dan bertahan, sementara disisi lain ruang yang tersedia (lahan) sangat terbatas. Hal ini akan berdampak pada munculnya beberapa penggunaan lahan perkotaan yang tidak semestinya seperti penggunaan bantaran sungai, bawah kolong jembatan, maupun ruang kosong lainnya yang tidak semestinya. Berkembangnya penggunaan lahan tersebut tentu akan berdampak pada kekumuhan kawasan tersebut, kondisi tersebut diperpuburk dengan tidak didukungnya sarana prasarana yang memadai sehingga berdampak pada munculnya berbagai permasalahan seperti kesehatan, kebersihan, kenyamanan, keamanan maupun lainnya. Kelurahan Gondoriyo merupakan salah satu kelurahan yang masuk dalam program KOTAKU yang ada di Kota Semarang. Dalam rangka pencegahan dan penanganan kumuh, maka diperlukan proses awal untuk mengetahui profil kekumuhan lokasi tersebut yang nantinya akan menjadi dasar dalam menangani permasalahan kumuh yang ada di Kleurahan Gondoriyo. Penelitian ini merupakan identifikasi awal terhadap kondisi kekumuhan Kelurahan Gondoriyo, sehingga metode yang digunakan adalah metode kuantitatif dengan melakukan analisa deskriptif kualitatif berdasarkan hasil orientasi lapangan (primer) maupun wawancara (sekunder), sehingga nantinya didapatkan data yang akurat dan valid yang kemudian diolah mengunakan spasial GIS. Adapun kondisi yang dianalisa menyangkut 7 indikator permukiman kumuh, yakni kondisi jalan, drainase, persampahan, sanitasi, air bersih, rumah tidak layak huni, dan kebencanaan,
\end{abstract}

Kata Kunci : Identifikasi, Profil, Kumuh

\begin{abstract}
The city is the center of population activity which is equipped with various facilities and infrastructure to support the needs of its inhabitants. The city is growing day by day in line with increasing population growth, both due to urbanization and other factors. Population growth in a city will certainly have an impact on the need for good space at least as a place to live and survive, while on the other hand the available space (land) is very limited. This will have an impact on the emergence of several improper uses of urban land such as the use of riverbanks, under bridges, and other inappropriate empty spaces. The development of this land use will certainly have an impact on the slums of the area, this condition is worsened by not being supported by adequate infrastructure so that it has an impact on the emergence of various problems such as health, cleanliness, comfort, security and others. Gondoriyo Village is one of the sub-districts included in the KOTAKU program in Semarang City. In the context of preventing and handling slums, an initial process is needed to determine the slum profile of the location which will later become the basis for dealing with slum problems in Gondoriyo Village. This research is an initial identification of the slum conditions of Gondoriyo Village, so the method used is a quantitative method by conducting qualitative descriptive analysis based on the results of field orientation (primary) and interviews (secondary), so that later accurate and valid data will be obtained which are then processed using spatial GIS. . The conditions analyzed include 7 indicators of slum settlements, namely road conditions, drainage, solid waste, sanitation, clean water, uninhabitable houses, and disasters.
\end{abstract}

Keywords: Identification, Profile, Slum

\section{PENDAHULUAN}

Berdasarkan Undang - Undang No. 4 Tahun 1992 mengenai Perumahan dan Permukman disebutkan bahwa rumah merupakan bangunan yang di fungsikan sebagai tempat tinggal maupun hunian bagi keluarga. Selain itu dijelaskan bahwa perumahan merupakan kelompok rumah yang di fungsikan sebagai tempat tinggal dengan adanya sarana dan prasarana lingkungan yang 
ada disekitarnya. Sedangkan permukiman adalah bagian dari lingkungan (Kota atau Desa) yang berfungsi sebagai tempat tinggal maupun hunian serta tempat diadakannya kegiatan dalam mendukung kehidupan masyarakat sekitarnya.

Dengan penjelasan perumahan dan permukiman tersebut, rumah sangat berfungsi sebagai bagian yang dapat dilihat secara fisik berdasarkan adanya proses berkembangannya dan berkaitan dengan mobilitas sosial dan ekonomi dari penguhini tersebut dalam kurun waktu di masa yang akan datang. (Eny Endang Surtiani, 2006)

Dengan jumlah penduduk yang semakin meningkat di Indonesia, menjadikan kebutuhan akan rumah pun sangat dibutuhkan oleh masyarakat. Berdasarkan (Asep Hariyanto, 2007) dijelaskan bahwa terdapat karakteristik kawasan kumuh di Indonesia yang menggambarkan kawasan permukiman yangg dapat dilihat berdasarkan kondisi lingkungan yang tidak sehat yang menandakan kawasan tersebut menjadi kumuh, salah satunya kawasan tersebut terlihat kotor, tercemar, lembab, dan lain - lain. Kondisi tersebut di timbulkan dengan ketidakmampuan adanya daya dukung lingkungan sekitar dalam mengatasi beban aktivitas di kawasan tersebut.

Selain menjelaskan kawasan kumuh yang menempatkan lahan - lahan legal, disebutkan juga "Slum Area" dijelaskan bahwa muncul adanya lahan - lahan tanpa hak, baik secara kepemilikan maupun fungsi dari runag kota yang merupakan lahan bukan sebagai tempat hunian. Selain itu kawasan semacam itu masuk kedalam kawasan squatter, yang merupakan suatu area hunian yang daapt dibangun di ata lahan tanpa dilindungi hak kepemilikan atas tanahnya tersebut.

Dalam pencegahan permukiman kumuh di Indonesia, salah satu program yang ada di Direktorat Jenderal Cipta Karya Kementrian Pekerjaan Umum dan Perumahan Rakyat dalam mempercepat permukiman kumuh di Indonesia dan mendukung "Gerakan 100-0100", yaitu 100 persen akses universal air minum, 0 persen permukiman kumuh, dan 100 persen akses sanitasi layak.

Tujuan adanya penelitian ini adalah identifikasi wilayah Kelurahan Gondoriyo, Kecamatan Ngaliyan sebagai kawasan pencegahan permukiman kumuh di Kota Semarang. Dalam identifikasi kondisi kawasan kumuh di Kelurahan Gondoriyo, dapat dilihat berdasarkan 7 indikator pencegahan permukiman kumuh, antara lain: Kondisi Jalan, Drainase, Persampahan, Sanitasi, Air Bersih, Rumah Tidak Layak Huni, dan Kebencanaan. Dalam kegiatan penelitian tersebut menggunakan beberapa metode dalam kebutuhan data yang diperlukan selama kegiatan penelitian tersebut, seperti metode kuantitatif dan metode kualitatif.

\section{DATA DAN METODE}

\subsection{Pendekatan}

Pendekatan yang digunakan dengan penelitian ini adalah Pendekatan Kualitatif

Pendekatan Kualitatif menurut (Corbin dan Strauss (2015:5) dalam Dr. Wahidmurni, 2017) merupakan bentuk dalam penelitian yang dimana dalam penelitian tersebut mengumpulkan data dengan cara memperoleh dan menganalisis yang telah didapatkannya yang dimana menjadi dari bagian dari proses penelitian sebagai partisipan bersama informan yang dapat memberikan sebuah data.

Penelitian yang menggunakan metode kualitatif ini lebih menekankan akan proses penelitian dibandingkan dengan hasil yang dicapai, selian itu dalam metode kualitatif ini menggambarkan juga sumber data dari hasil observasi lapangan. Selain itu sifat dari metode tersebut adalah induksi yang dimana berupa fakta yang empiris, jadi dapat dilakukan di saat lokasi lapangan tersebut. Sumber - sumber dalam penelitian kualitatif ini menggunakan studi referensi berdasarkan hasil penelitian yang sudah pernah muncul sebelumnya.

\subsection{Pengumpulan Data}

Dalam pengumpulan data ini, data yang sebagai masukan dalam proses analisa dapat melakukan sebuah pengumpulan data, maka keperluan penelitian seperti jenis data yang harus dipersiapkan.

Oleh karena itu, dalam penelitian ini perlu adanya desain kebutuhan data serta metode yang dapat digunakan secara sistematis dalam memudahkan proses pengumpulan data. 
Adapun tahapan - tahapan dalam metode pengumpulan data pada penelitian ini, antara lain:

- Desain Kebutuhan Data

Dalam identifikasi data maupun adanya penentuan data yang diperlukan dalam proses penelitian tersebut.

- Teknik Pengumpulan Data

Dalam Teknik pengumpulan data dengan cara pengumpulan data yakni dengan observasi, wawancara, dan FGD (Focus Group Discussion).

- Kompilasi Data

Merupakan pengklasifikasian data yang dapat diperoleh dalam mempermudah intepretasi dalam pengeolahan data selanjutnya.

\subsection{Pengolahan Data}

Pengolahan data yang digunakan dalam penelitian ini, antara lain:

a) Penyajian Data

Dalam penyajian data yang dihasilkan dalam penelitian ini akan disajikan dalam bentuk deskriptif, bentuk tabel dan gambar, peta, serta dokumentasi lapangan dalam memudahkan dalam intepretasi dan pemahan dalam hasil penelitian tersebut.

b) Metode Pelaksanaan Kegiatan

- Persiapan Studi

Menyiapkan perangkat, peralatan, perlengkapan dalam pelaksanaan kegiatan penelitian sebagai koordinasi dan pembagian tim.

- Penentuan Indikator penentuan indikator yang digunakan dalam penelitian ini menggunakan analisis spasial.

- Pengolahan dan Analisis Data

Pengolahan data menggunakan software GIS, dengan analisis deskriptif.

\subsection{Metode Analisis}

Dalam proses analisis dapat dijelaskan analisis yang akan digunakan sesuai dengan tujuan dan sasaran yang ingin dicapai dalam penelitian ini, antara lain:

a) Analisis Deskriptif; Dimana analisis ini menggambarkan yang biasanya didapat setelah memperoleh data yang telah di dapatkan nya, selain itu menggambarkan kondisi dan keadaan wilayah di kawasan tersebut. Umumnya metode ini berupa uraian dan narasi yang harus mempresentasikan keadaan sebenarnya.

b) Analisis Spasial; Analisis spasial digunakan untuk mengkaji data dan informasi yang mengandung data yang bersifat numeric dan keruangan. Analisis ini juga digunakan untuk menginterpretasikan hasil analisis kedalam spasial dalam bentuk pemetaan.

\section{HASIL DAN PEMBAHASAN}

Kelurahan Gondoriyo, Kecamatan Ngaliyan merupakan kelurahan yang dimana tidak ditemui kawasan kumuh, dan juga Kelurahan Ngaliyan teridentifikasi sebagai pencegahan kawasan permukiman kumuh. Wilayah yang asli permukiman di Kelurahan Gondoriyo yakni RW 01,02,03, dan 04.

Wilayah yang teridentifikasi kumuh di Kelurahan Gondoriyo, terdapat di RW 02, RT 01,02,03. RW 02 yang merupakan salah satu permukiman asli dan teridentifikasinya kawasan pencegahan kumuh. Luas wilayah RW 02 yang terindikasi kumuh tersebut adalah 194,59 $\mathrm{Ha}$.

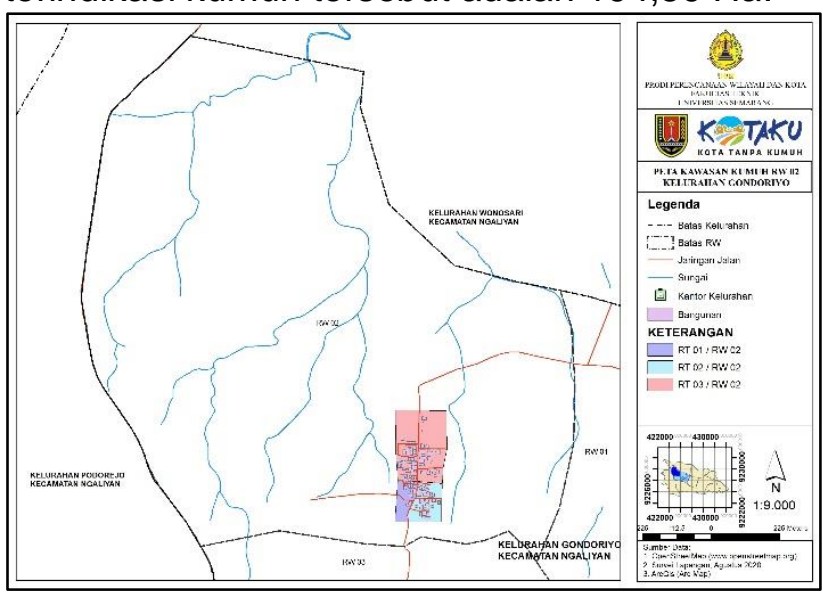

Sumber: Analisis Individu

\section{Gambar 1. Peta Kawasan Kumuh RW 02, Kelurahan Gondoriyo}

Dengan permasalahan tersebut dapat dilihat di 7 aspek permasalahan, yakni dengan melihat kondisi jalan, drainase, persampahan, sanitasi, air bersih, kondisi rumah layak huni, 
dan kebencanaan, dapat dijelaskan sebagai berikut:

\subsection{Kondisi Jalan}

Berdasarkan kondisi eksisting pada tahun 2020 kondisi jalan di RW 02 sudah di beton atau sudah baik di sepanjang jalan lingkungan di RW 02, namun terdapat titik kerusakan atau retaknya jalan di RT 02 RW 02 yang di akibatkan oleh pergeseran tanah akibatnya jalan tersebut retak, selian itu terdapat di beberapa titik jalan tersebut masih tanah belum beraspal atau beton. Untuk itu dilakukan sebuah pemeliharaan jalan dan perbaikan jalan tersebut.

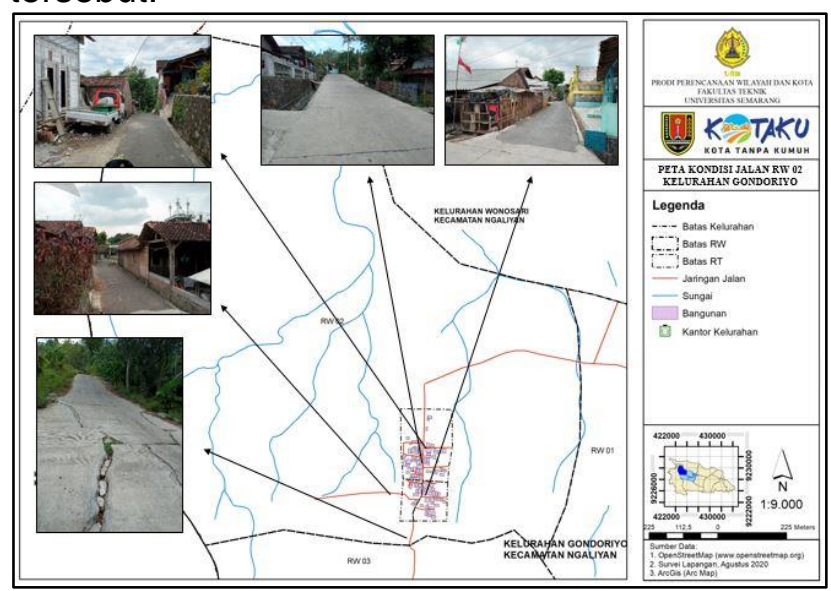

Sumber: Analisis Individu

\section{Gambar 2. Peta Kondisi Jalan RW 02,} Kelurahan Gondoriyo

\subsection{Kondisi Drainase}

Kondisi saluran drainase di RW 02 sudah cukup baik, drainase yang berada di jalan utama RW 02 tersebut dengan kedalam yang sudah sesuai dan lebar yang sesuai menjadikan drainase tersebut dapat menampung air pembuangannya, namun meskipun sudah baik, terdapat sampah dan rumput liar yang dapat menjadi permasalahan pada drainase, untuk itu guna memperlancar saluran drainase tersebut dilakukanlah sebuah pemeliharaan yang lebih yang bisa dilakukan oleh masyarakat sekitar dengan cara gotong royong dalam membersihkan rumput dan sampah yang menghambat mengalirnya saluran drainase disepanjang drainase RW 02.

Apabila pada saat musim hujan, saluran drainase tersebut dapat menampung aliran air tanpa adanya hambatan dari permasalahan sampah tersebut, berikut merupakan kondisi dan dokumentasi eksisting jaringan drainase di RW 02 Kelurahan Gondoriyo.

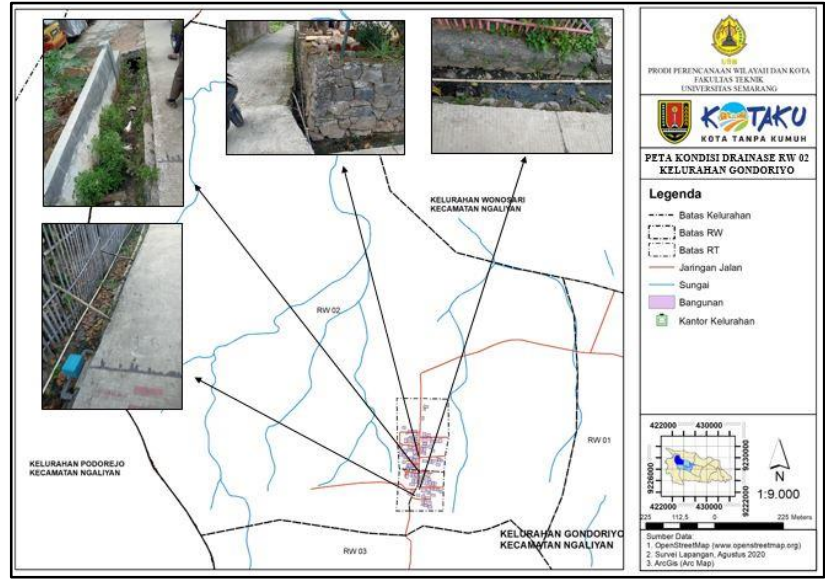

Sumber: Analisis Individu

Gambar 3. Peta Kondisi Drainase RW 02, Kelurahan Gondoriyo

\subsection{Kondisi Persampahan}

Setiap rumah di RW 02 Kelurahan Gondoriyo, terdapat tempat/bak sampah di masing - masing rumah, namun belum adanya pengelolaan seperti pengepul atau bank sampah di RW 02 tersebut, maka dari itu sampah yang telah terbuang di tempat sampah langsung diambil oleh petugas sampah yang langsung di buang ke TPS Kelurahan Gondoriyo yang berada di RW 03. Selain itu terdapat sampah di sepanjang drainase jalan lingkungan tersebut.

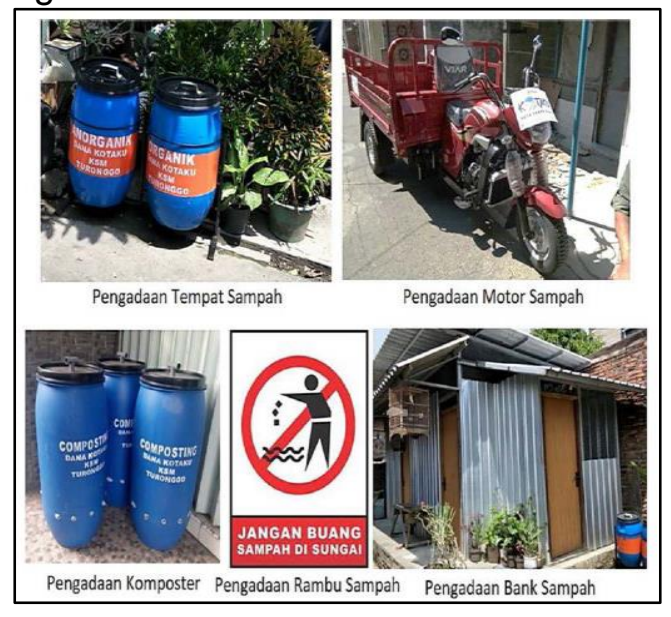




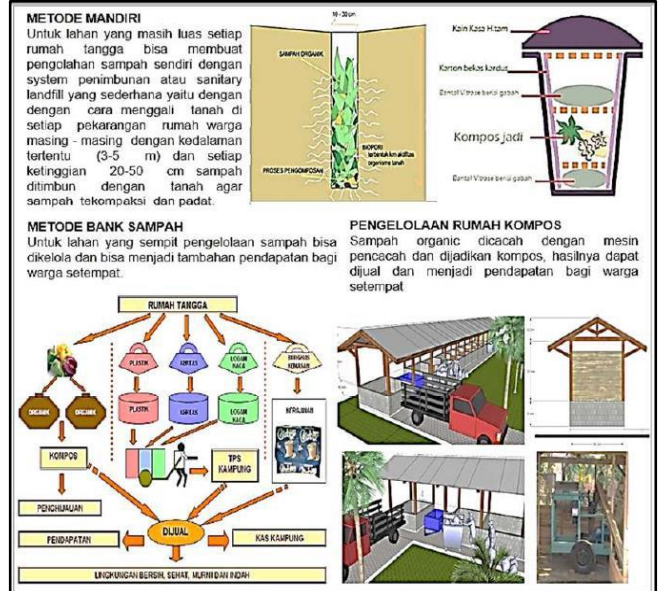

Sumber: Dokumen RPLP Kelurahan Gondoriyo, 2016

Gambar 4. Rencana Pengelolaan Sampah di RW 02

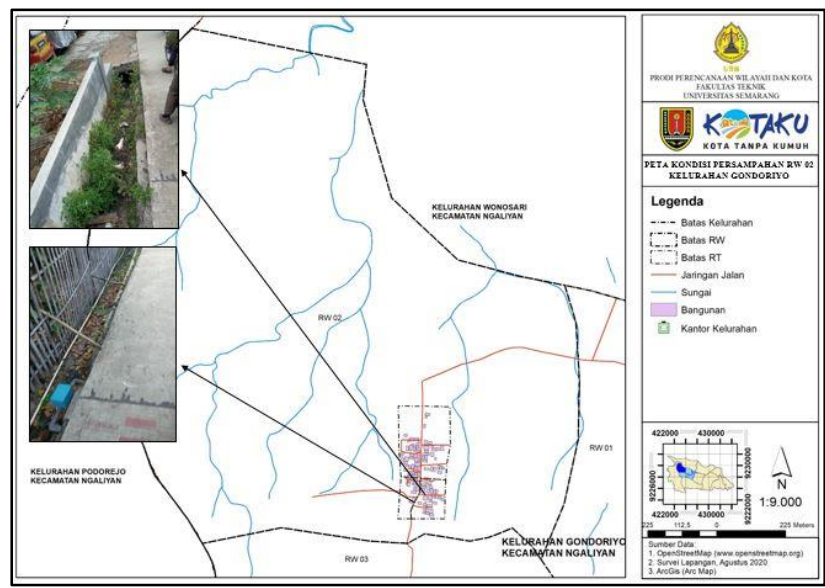

Sumber: Analisis Individu

\section{Gambar 5. Peta Kondisi Persampahan RW 02, Kelurahan Gondoriyo}

\subsection{Kondisi Sanitasi}

Kondisi sanitasi di RW 02 Kelurahan Gondoriyo belum adanya IPAL (Instalasi Pengelolaan Air Limbah), untuk itu pembuangan air limbah langsung ke drainase lingkungan yang terkadang dapat mencemari drainase lingkungan tersebut. Namun terdapat beberapa rumah yang drainase tersebut sangat sempit dan terhambat, sehingga belum lancarnya pengaliran yang terjadi, akibatnya terlihat menjadi kumuh. Selain itu setiap rumah sudah tersedia kamar mandi atau MCK masing - masing serta tidak ada permasalahan perihal MCK pribadi di RT 01, 02, 03 RW 02 Kelurahan Gondoriyo

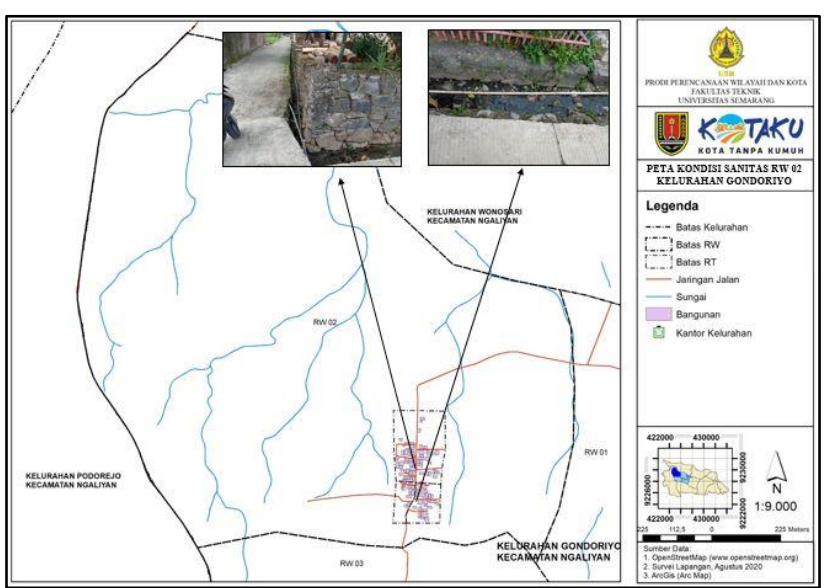

Sumber: Analisis Individu

\section{Gambar 6. Peta Kondisi Sanitasi RW 02, Kelurahan Gondoriyo}

\subsection{Kondisi Air Bersih}

Kondisi Air Bersih yang ada di RW 02 sudah tersalurkan dengan baik yaitu adanya PAMSIMAS di setiap RW, salah satunya terdapat tower air di RW 02 yang lalu di salurkan langsung menuju rumah masing masing di RT 01, 02, 03 RW 02. Meskipun begitu, guna mengurangi kelangkaan air bersih di RW 02 yang jauh dengan permukiman lainnya dibutuhkan penyediaan air yang bertambah di kawasan tersebut.

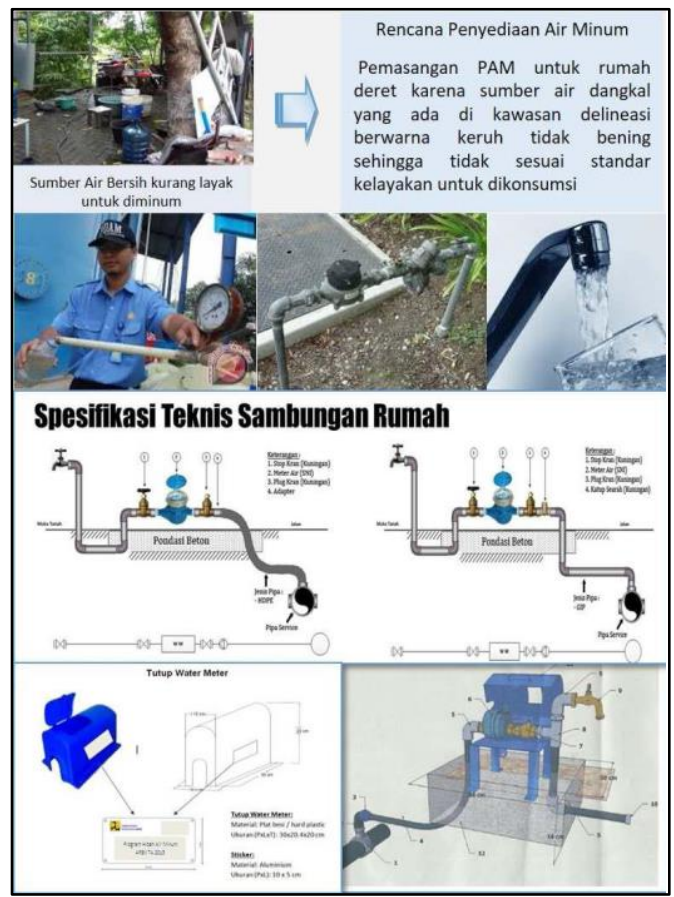

Sumber: Dokumen RPLP Kelurahan Gondoriyo, 2016 


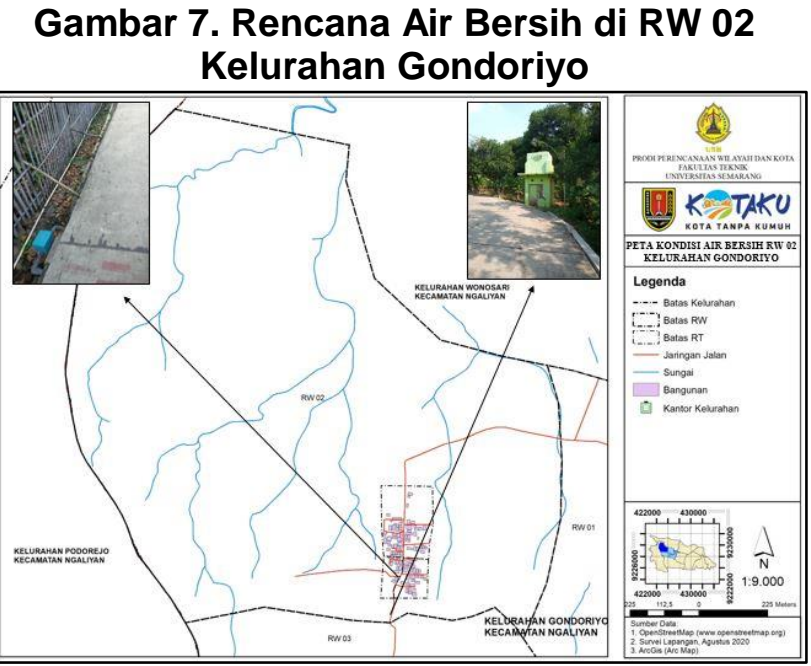

Sumber: Analisis Individu

Gambar 8. Peta Kondisi Sanitasi RW 02, Kelurahan Gondoriyo

\subsection{Kondisi Rumah Tidak Layak Huni}

Rumah tidak layak huni di Kelurahan Gondoriyo tepatnya di RW 02 terdapat beberapa rumah yang harus untuk dibenahi, selain itu juga terdapat rumah yang belum layak huni meskipun hanya beberapa. Namun dengan ini pembangunan hunian dengan memperhatikan aturan KDB/KLB bangunan.

Berdasarkan survey yang dilakukan terdapat bagunan rumah yang tidak layak huni di RT 1,2,3 RW 002, dapat dilihat pada tabel berikut ini:

Tabel 1. Jumlah Rumah Tidak Layak Huni di RW 02

\begin{tabular}{|l|l|c|c|}
\hline \multirow{2}{*}{ No } & \multirow{2}{*}{$\begin{array}{l}\text { Wilayah } \\
\text { (RW 02) }\end{array}$} & $\begin{array}{c}\text { Jenis RTLH } \\
\text { Perbaikan dan } \\
\text { Pembangunan }\end{array}$ & $\begin{array}{c}\text { Rumah } \\
\text { Tidak } \\
\text { Sesuai } \\
\text { peraturan }\end{array}$ \\
\hline 1 & $\begin{array}{l}\text { RT 01 / } \\
\text { RW 02 }\end{array}$ & 3 Unit & 3 Unit \\
\hline 2 & $\begin{array}{l}\text { RT 02 / } \\
\text { RW 02 }\end{array}$ & 3 Unit & 1 Unit \\
\hline 3 & $\begin{array}{l}\text { RT 03 / } \\
\text { RW 02 }\end{array}$ & 10 Unit & - \\
\hline \multicolumn{2}{|c|}{ Jumlah } & 16 Unit & 4 Unit \\
\hline
\end{tabular}

Sumber: Hasil Analisis, 2020

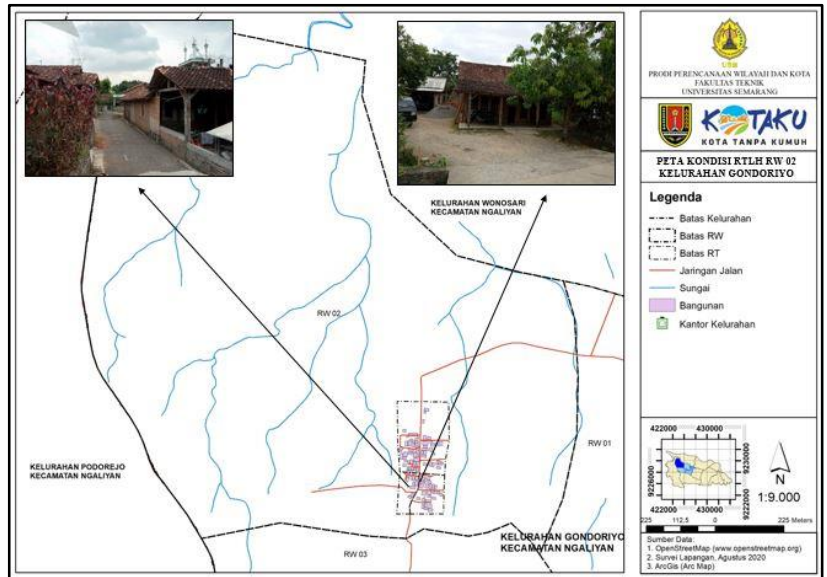

Sumber: Analisis Individu

Gambar 9. Peta Kondisi Rumah Tidak Layak Huni RW 02, Kelurahan Gondoriyo

\subsection{Kondisi Kebencanaan}

Kondisi bencana di RW 02 minim dengan adanya bencana, namun daerah kawasan yang ada di RW 02 tersebut dekat dengan hutan maupun terdapat tebing, yang menjadikan kawasan tersebut menjadi rawan oleh bencana longsor. Selain rawan dengan bencana longsor, guna mengurangi kebakaran di sekitar permukiman yang ada di RW 02, sangat dibutuhkan alat pemadam kebakaran guna pencegahan kebakaran di kawasan tersebut seperti pengadaan motor pemadam dan pengadaan Alat Pemadam Api Ringan (APAR).

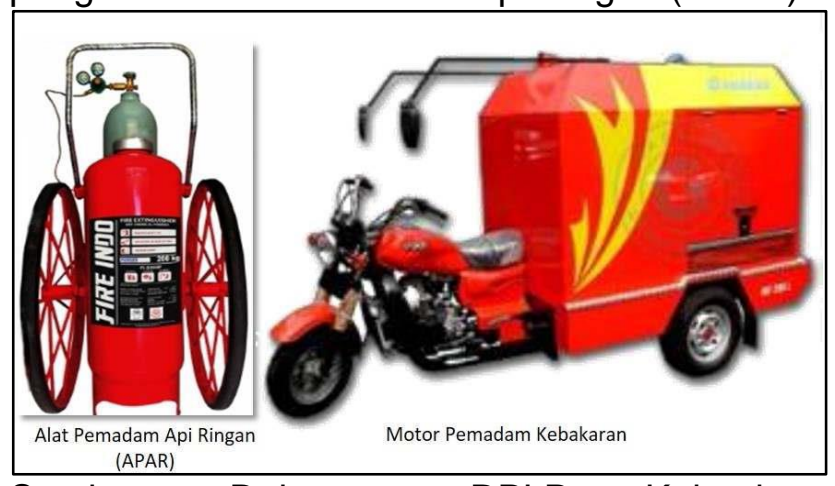

Sumber: Dokumen RPLP Kelurahan Gondoriyo, 2016

Gambar 10. Pencegahan Kebakaran di RW 02 Kelurahan Gondoriyo 


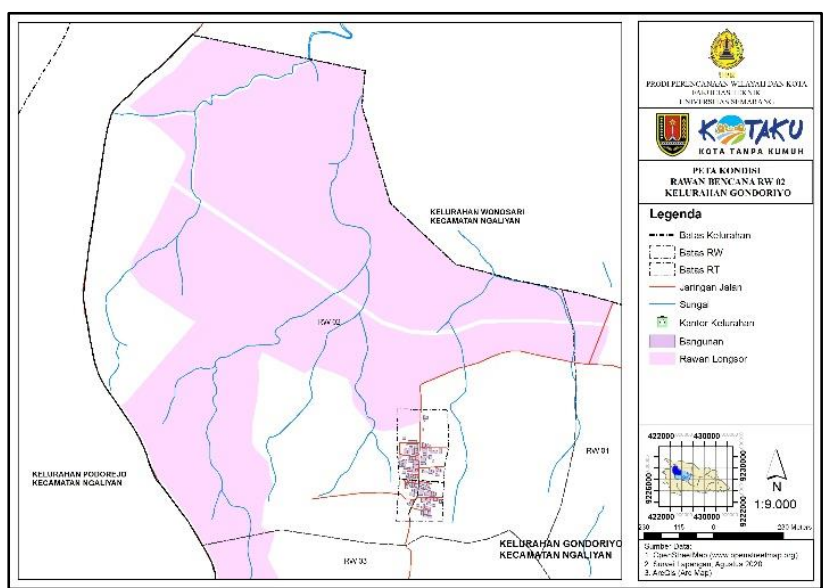

Sumber: Analisis Individu

Gambar 11. Peta Kondisi Kebencanaan RW 02, Kelurahan Gondoriyo

\section{SIMPULAN}

Berdasarkan 7 indikator permukiman kumuh, seperti kondisi jalan, drainase, persampahan, sanitasi, air bersih, rumah tidak layak huni, dan kebencanaan yang berada di RW 02 Kelurahan Gondoriyo, dilihat berdasarkan kondisi eksisting permasalahan yang sebelumnya terjadi sudah teralisasi dalam penanganan permasalahan bidang infrasturktur di kawasan tersebut. Untuk itu dengan adanya penelitian ini, berbagai aspek seperti pemerintah dan masyarakat maupun lembaga penting dalam mengetahui kondisi permukiman di Kelurahan Gondoriyo tersebut, selain tiu dengan mengetahui permasalahan maupun pemeliharaan sangat penting bagi masyarakat dalam melakukan pencegahan permukiman kumuh di RW 02 Kelurahan Gondoriyo.

\section{REFERENSI}

Undang - Undang Republik Indonesia Nomor 4 Tahun 1992 Tentang Perumahan dan permukiman

Surtiani, Eny Endang. 2006. Faktor - Faktor yang Mempengaruhi Terciptanya Kawasan Permukiman Kumuh di Kawasan Pusat Kota (Studi Kasus: Kawasan Pancuran, Salatiga). Semarang: Universitas Diponegoro.

Danim, Sudarwan. 2002. Menjadi Peneliti Kualitatif. Bandung: Pustaka Setia

Hariyanto, Asep. 2007. Strategi Kawasan Kumuh Sebagai Upaya Menciptakan lingkungan perumahan dan permukiman yang sehat (Contoh Kasus: Kota Pangkalpinang). Bandung: UNISBA Jurnal Perencanaan Wilayah dan Kota UNISBA 7.2 (2007): 11-37.

Wahidmurni, W. 2017. Pemaparan Metode Penelitian Kualitatif. Malang: UIN Malang 